\title{
Proces integracji z Unią Europejską a przemiany strukturalne w przemyśle Polski
}

W marcu 1992 roku weszła w życie tzw. Umowa Przejściowa, tj. ta część Układu o stowarzyszeniu Polski z Wspólnotami Europejskimi (podpisanego w grudniu 1991 roku), która bezpośrednio dotyczyła wzajemnej wymiany handlowej. Stanowi ona podstawę prawną do utworzenia strefy wolnego handlu wyrobami przemysłowymi. Procesy integracyjne uwidoczniły jednak znaczną lukę strukturalną miedzy przemysłem polskim a zachodnioeuropejskim.

Dostosowanie struktury do skutecznego konkurowania na jednolitym rynku europejskim, stało się podstawowym celem strategii rozwoju przemysłu w Polsce.

Pierwsze lata transformacji systemu gospodarczego wykazały, że wewnętrzne źródła akumulacji kapitału, w odniesieniu do skali restrukturyzacji przemysłu, wobec relatywnie dużego udziału w produkcie krajowym brutto (PKB) wydatków na konsumpcję i niskiej stopie oszczędności, są dalece niewystarczające. Uzależnia to wzrost efektywności i innowacyjności, a w konsekwencji konkurencyjności polskiego przemysłu od napływu kapitału zagranicznego.

W latach 1990-2000 wartości bezpośrednich inwestycji zagranicznych w Polsce zwiększyła się ze 105 mln USD do 49,4 mld USD, co stawia ją na pierwszym miejscu wśród krajów Europy Środkowej i Wschodniej. Najwięcej, bo ponad $60 \%$ kapitału zainwestowali inwestorzy z krajów Unii Europejskiej.

Prawie $43 \%$ kapitału inwestorzy zagraniczni zainwestowali w przemyśle, w tym zwłaszcza w przemyśle spożywczym i motoryzacyjnym. Świadczy to o ich szczególnym zainteresowaniu tzw. przemysłami rynkowymi, głównie produkcją wyrobów o dużym i trwałym popycie, którymi bez wątpienia są artykuły spożywcze i samochody osobowe' ${ }^{1}$.

Napływowi bezpośrednich inwestycji zagranicznych towarzyszył wzrost eksportu. W latach 1990-2000 jego wartość zwiększyła się z 14,3 mld USD do 28,8 mld USD, natomiast udział w nim przedsiębiorstw z kapitałem zagranicznym - z $6 \%$ do $51,6 \%$.

\footnotetext{
' W latach dziewięćdziesiatych Poiska stała się jednym z najatrakcyjniejszych rynków motoryzacyjnych w Europie, o czym świadczy sprzedaż 630 tys. nowych samochodów osobowych w 1999 roku. Rosnące ceny pojazdów (wzrost stawki podatku akcyzowego), kredytów, ubezpieczeń i paliw oraz import 210 tys. samochodów używanych spowodowały, że w 2000 roku sprzedaż zmniejszyła się o 160 tys.
} 
Znaczącej zmianie uległa struktura geograficzna eksportu. Udział krajów Unii Europejskiej przekroczył 70\% (w 1985 roku - 21,6\%), natomiast krajów Europy Środkowej i Wschodniej zmniejszył się do 17,3\% (w 1985 roku $-49 \%$ ).

Rzeczywistym miernikiem konkurencyjności polskiego przemysłu stała się wielkość i struktura eksportu.

W 2000 roku wartość polskiego eksportu w przeliczeniu na jednego mieszkańca wyniosła 730 USD $\mathrm{i}$ była znacznie niższa $\mathrm{w}$ porównaniu $\mathrm{z}$ analogicznym wskaźnikiem w krajach Unii Europejskiej (np.: Belgia - 17560 USD, Irlandia - 17479 USD, Hiszpania 2737 USD, Portugalia - 2434 USD), jak i w niektórych krajach Europy Środkowej i Wschodniej (np.: Czechy - 2561 USD, Węgry - 2276 USD, Słowacja - 1989 USD).

Strukturę towarową polskiego eksportu charakteryzuje $75 \%$ udział wyrobów: surowcochłonnych, pracochłonnych i o technologii bazowej. Zaledwie $25 \%$ jego wartości stanowią wyroby technologicznie intensywne oparte na technologii innowacyjnej lub na dostawach komponentów.

Wyroby surowcowochlonne (meble 2139 min USD, węgiel kamienny $981,7 \mathrm{mln}$ USD)

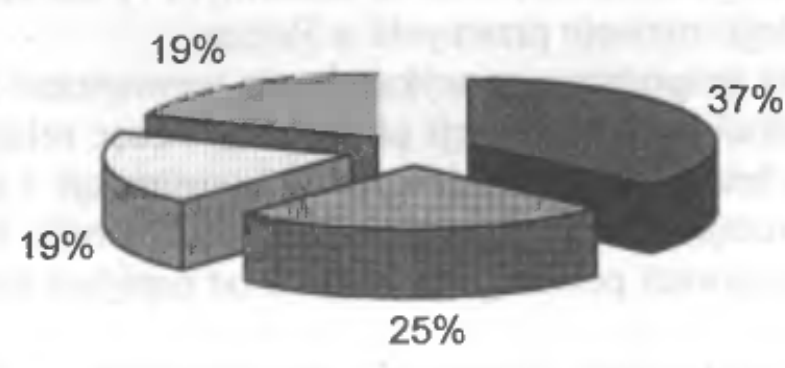

国 Wyroby technologicznie intensywne oparte na technologii inniwacyjnej lub na dostawach komponentów (samochody osobowe i ciçzarowe oraz ich części i podzespoly - $2500 \mathrm{mln}$ USD. statki morskie - 1032 mln USD, telewizory - $510 \mathrm{mln}$ USD)

$\square$ Wyroby o technologii bazowej (półwyroby z zelaza i stali niestopowej 2057 mln USD, miedź katodowa, wlewki okrągłe, walcówka miedziana $664 \mathrm{mln}$ USD)

$\square$ Wyroby pracochłonne (odzież - 2159 mln USD)

Źródło: opracowanie własne na podstawie danych Ministerstwa Gospodarki

Ryc. 1. Struktura polskiego eksportu (główne wyroby eksportowe i ich wartość)

Dzięki bezpośrednim inwestycjom zagranicznym, zaliczane do wyrobów technologicznie intensywnych, samochody osobowe i ciężarowe oraz ich części i podzespoły są głównym towarem eksportowym Polski, a w grupie przedsiębiorstw - największych eksporterów znalazły się: Fiat Auto Poland, Volkswagen Motor Polska Polkowice i Volkswagen Poznań. Łączne przychody z eksportu tych firm w roku 2000 wyniosły ponad 8 mld zł. Znaczące przychody z eksportu osiagają również firmy: Opel Polska Gliwice, który w 2000 roku wyeksportował 82 tys. samochodów osobowych i Isuzu Motors Tychy - producent silników do samochodów osobowych i łodzi motorowych. 
Również dzięki bezpośrednim inwestycjom zagranicznym ważnym towarem eksportowym, zaliczanym do wyrobów technologicznie intensywnych, są telewizory, a ich producenci: Philips Consumer Electronics Industries Poland Kwidzyn i Thomson Polkolor Piaseczno należą do grupy największych eksporterów. Telewizory eksportują również: Daewoo EM Pruszków i LG Electronics Mława.

Tradycyjnie wysoką pozycję wśród towarów eksportowych zajmują, zaliczane do wyrobów technologicznie intensywnych, statki morskie. Polski przemysł stoczniowy, reprezentowany przez należące do grupy czołowych eksporterów - Stocznia Porta Holding Szczecin i Stocznia Gdynia, specjalizuje się w budowie kontenerowców. Konkurencja stoczni z Korei Południowej, które w 2000 roku przejęły większość światowych zamówień na budowę kontenerowców, spowodowała konieczność budowy w polskich stoczniach nowych typów statków, w tym wielu prototypowych. Należą do nich m.in. chemikaliowce, gazowce i masowce wielozadaniowe charakteryzujące się złożoną konstrukcją oraz wymagające zastosowania specjalnych materiałów.

Tabela 1. Najwięksi eksporterzy w 2000 roku

\begin{tabular}{|l|l|c|c|}
\hline Lp. & Nazwa przedsiębiorstwa, miejscowośc & $\begin{array}{c}\text { Przychody z eksportu } \\
\text { (w tys. zl) }\end{array}$ & $\begin{array}{c}\text { Udzial eksportu } \\
\text { w sprzedaży (w \%) }\end{array}$ \\
\hline 1 & Fiat Auto Poland, Biclsko - Biała & 3443638,67 & 51,77 \\
\hline 2 & KGHM Polska Miedź, Lubin & 3266200,95 & 65,55 \\
\hline 3 & Volkswagen Motor Polska, Polkowice & 3189901,99 & 97,15 \\
\hline 4 & Węglokoks, Katowice & 3005018,97 & 82,12 \\
\hline 5 & Stocznia Gdynia, Gdynia & 2278867,74 & $102,48 *$ \\
\hline 6 & Philips CEI Polska, Kwidzyn & 1639415,80 & 91,47 \\
\hline 7 & Huta Katowice, Dabbrowa Górnicza & 1467732,10 & 38,80 \\
\hline 8 & Thomson Polkolor, Piaseczno & 1438672,51 & 65,93 \\
\hline 9 & Volkswagen Poznań, Poznań & 1384208,34 & 51,18 \\
\hline 10 & Stocznia Szczecińska Porta, Szczecin & 1225473,33 & 70,34 \\
\hline 11 & Rafineria Gdańska, Gdańsk & 960573,24 & 13,75 \\
\hline 12 & Frantschach Świecie, Świecie & 775049,77 & 62,17 \\
\hline 13 & Polski Koks, Katowice & 751328,12 & 55,17 \\
\hline 14 & International Paper, Kwidzyn & 748280,27 & 43,27 \\
\hline 15 & Police Zakłady Chemiczne, Police & 721979,27 & 52,96 \\
\hline
\end{tabular}

* Udział eksportu w sprzedaży jest to relacja eksportu do przychodów ze sprzedaży. Udział ten może być wyższy niż 100\%, gdy przychody z działalności podstawowej są niższe od wartości eksportu.

Źródło: opracowanie własne na podstawie - Rzeczpospolita, 2001, .Najwięksi w Rzeczpospolitej”, 8.05.2001

Inwestorzy zagraniczni mają też decydujący udział w eksporcie mebli. W latach 1999-2000 udział eksportu w produkcji przemysłu meblarskiego zwiększył się z 31\% do 76,3\%. Czołowymi eksporterami w tej branży są przede wszystkim: Mazurskie, Bydgoskie, Słupskie, Goleniowskie, Pomorskie, Czerskie i Gościnińskie Fabryki Mebli przejęte przez kapitał niemiecki, kontrolujący $70 \%$ produkcji mebli w Polsce ${ }^{2}$. W strukturze eksportu ponad

${ }^{2}$ Polska jest czołowym europejskim eksporterem mebli. Trzecia (po Włoszech i Niemczech) pozycja wśród europejskich producentów mebli i pierwsza wśród wytwórców mebli do siedzenia jest efektem 
$50 \%$ stanowią meble do siedzenia. Udział części do produkcji mebli stanowi $11 \%$ eksportu. Na podkreślenie zasługuje fakt, że coraz więcej fabryk zmienia strategię działania na rynku niemieckim, będącym największym odbiorcą polskich mebli $(66,2 \%$ eksportu mebli do siedzenia i $49,9 \%$ eksportu pozostałych mebli i ich części). Dotychczasowy eksport mebli produkowanych na zlecenie i według wzorów niemieckich kontrahentów, zostaje zastępowany umowami $\mathrm{z}$ niemieckimi dystrybutorami, którzy pośredniczą w sprzedaży polskich mebli projektowanych przez producentów.

W latach dziewięćdziesiątych zmieniła się pozycja Polski na międzynarodowym rynku węgla kamiennego. W 1978 roku, z eksportem wielkości 40,1 mln ton, polski przemysi wydobywczy ustępował jedynie północnoamerykańskiemu. Konkurencja tańszego węgla z krajów pozaeuropejskich, spowodowała, że obecna pozycja Polski ze sprzedażą - 23 mln ton, nie jest uznawana za wiodącą. W listopadzie 2000 roku po raz pierwszy eksport węgla stał się opłacalny. Przyczynił się do tego wzrost cen węgla w portach Europy Zachodniej ${ }^{3}$ przy równoczesnym zmniejszeniu kosztów wydobycia w Polsce. Wcześniej cena 1 tony węgla eksportowego była niższa o 28 zł od kosztów jej wydobycia, natomiast w listopadzie 2000 roku była wyższa o $1,6 \mathrm{zł}$.

Liczące się miejsce odzieży wśród towarów eksportowych wynika w dużej mierze z tzw. eksportu przerobowego, polegającego na szyciu odzieży z materiałów dostarczonych z zagranicy zgodnie $\mathrm{z}$ wzorami dostawcy i pod marką zleceniodawcy. W procesie tym uczestniczy większość przedsiębiorstw przemysłu odzieżowego, w tym notowane na giełdzie spółki: Bytom, Próchnik Łódź, Wólczanka Łódź, Vistula Kraków i Delia Zamość.

Tradycyjnie znaczącą pozycję wśród towarów eksportowych zajmują wyroby przemysłu metalurgicznego, zarówno hutnictwa żelaza, jak i hutnictwa miedzi. Znacznie lepiej rozbudowane od działów przetwórczych działy surowcowe hut powodują że, dominuje eksport półwyrobów z żelaza i stali niestopowej oraz miedzi katodowej, wlewek okrągłych i walcówki miedziowej. Ma to niekorzystny wpływ na relacje w handlu zagranicznym wyrobami hutniczymi. W 2000 roku za tonę wyrobów stalowych eksportowanych z Polski dostawcy otrzymywali średnio 250 USD, natomiast za tonę wyrobów importowanych odbiorcy płacili 550 USD. Spośród przedsiębiorstw przemysłu metalurgicznego w grupie największych eksporterów znalazły się: KGHM Polska Miedź Lubin i Huta Katowice Dąbrowa Górnicza.

Dotychczasowe zaangażowanie się kapitału zagranicznego w proeksportową restrukturyzację polskiego przemysłu należy uznać za niedostateczne ${ }^{4}$.

Dominujący udział w strukturze eksportu wyrobów surowcowochłonnych, pracochłonnych i o technologii bazowej świadczy o cenowym charakterze konkurencyjności polskiego przemysłu, co powoduje wrażliwość eksportu na wahania koniunktury gospodarczej na rynkach zagranicznych.

kompleksowej modernizacji przemysłu meblarskiego w Polsce, glównie poprzez zaangażowanie kapitału zagranicznego.

${ }^{3}$ Ceny węgla na rynkach Europy Zachodniej są ustalane na linii Amsterdam - Rotterdam - Antwerpia przez eksporterów pozaeuropejskich, w tym zwłaszcza przez Republikę Południowej Afryki.

${ }^{4}$ Niewystarczające zaangażowanie inwestorów zagranicznych w proeksportowe dziedziny polskiej gospodarki po części wiąże się z motywami ich inwestowania w Polsce. Dla większości firm zagranicznych podstawowym motywem do rozpoczęcia działalności stała się chlonność dużego rynku wewnętrznego. 
Zarówno w produkcji samochodów osobowych, jak i telewizorów zaliczanych do wyrobów technologicznie intensywnych, oprócz kapitału inwestorzy zagraniczni wnieśli własne technologie i rozwiązania konstrukcyjne. Również pomimo postępującego procesu "polonizacji”, zwłaszcza produkcji samochodów osobowych, większość komponentów pochodzi z zagranicy. W efekcie, przedsiębiorstwa $\mathrm{z}$ kapitałem zagranicznym ponoszą odpowiedzialność za ponad $62 \%$ deficytu polskiego handlu zagranicznego, który w 2000 roku wyniósł 15,9 mld USD.

Dużą rolę w proeksportowej restrukturyzacji przemysłu odgrywa polityka państwa, w tym zwłaszcza regulacje prawne warunkujące zainteresowanie potencjalnych inwestorów. Uwarunkowania prawne motywujące kapitał zagraniczny do lokowania się w priorytetowych dziedzinach gospodarki, promujące działalnosć proeksportową powinny stanowić filar polskiej polityki przemysłowej.

Obecnie możliwość udzielania pomocy dla inwestorów regulowana jest ramowo przez Ustawę o pomocy publicznej oraz szczegółowo przez Ustawę o specjalnych strefach ekonomicznych. Jednak powyższe regulacje prawne wymagają zmiany, gdyż nie zapewniają wzmożonego zainteresowania potencjalnych inwestorów.

Niezbędne jest również stworzenie systemu wspierania eksportu, obejmującego: ubezpieczenia kredytów eksportowych, dopłaty do nich, poręczenia i gwarancje, pomoc wiązaną (udzielanie zagranicznym odbiorcom celowego kredytu na zakup polskich towarów), uproszczenie procedur celnych i promocja eksportu.

\section{Literatura}

Apanowicz P., 2001, Gotówka za miejsca pracy, 14.02.01, Rzeczpospolita.

Apanowicz P., 2001, Polska - liderem w regionie, 23.02.01, Rzeczpospolita.

Durka B. (red.), 2000, Inwestycje zagraniczne w Polsce, Instytut Koniunktur i Handlu Zagranicznego, Warszawa.

Ners K. J., 2000, Popieranie eksportu, Nowe Życie Gospodarcze 12/252.

Rzeczpospolita, 2001, Najwięksi w Rzeczpospolitej, 8.05.01.

\footnotetext{
${ }^{5}$ Typowym przykładem efektu motywującej polityki gospodarczej jest budowa fabryki kineskopów Philipsa w Czechach. Decyzję o tej lokalizacji ułatwiła oferta dziesięcioletniego zwolnienia z podatku od osób prawnych, preferencyjna cena sprzedaży ziemi oraz bezpośrednie wsparcie czeskiego rządu w wysokości 40 mln EURO, z przeznaczeniem na rozbudowę lokalnej infrastruktury.
} 